\title{
사하라이남 아프리카지역의 종족갈등과 빈곤
}

권유경 (KOICA 서아프리카팀 전문연구원)

목 차

I. 서론

II. 종족갈등과 빈곤

1. 개념정의

2. 종족갈등과 빈곤을 보는 시각

III. 사하라이남 아프리카지역의 종족갈등과 빈곤

1. 종족갈등의 현황과 특성

2. 빈곤 현황 및 내용

3. 종족갈등과 빈곤의 연관성

IV. 나이지리아 사례 분석

1. 왜 나이지리아인가?

2. 나이지리아 종족갈등

3. 나이지리아의 종족갈등과 빈곤

$\mathrm{V}$. 정리 및 결론

\section{I. 서론}

전세계적으로 빈곤퇴치에 많은 관심을 가지고 이를 위해 막대한 규모의 재원이 쏟아지는 가운데 세계 여러 지역에서 빈곤은 괄목할만한 성과를 드러내며 감소추세를 나타낸다. 그러나 유일하게 사하라이남 아프리카지역은 인구의 약 $48 \%$ 가 하루 1.25 달러 미만의 생활을 하고 있으며 이러한 인구는 인구증가와 더불어 90 년대 2억 9,000만명에서 2010년 4억 1,400만명으로 오히려 크게 늘었다 (UN 2013:7). 
그간 아프리카지역이 이처럼 빈곤퇴치에 어려움을 겪는 이유로는 제도, 정책적 실패, 게으른 국민성 같은 내재적 설명과 기후, 환경으로 인한 열대 질병과 같은 외부 조건들이 주로 지적되어왔다. 그러나 낮은 국민소득과 질병, 기근이 만연해있는 상황에서 국가의 시스템이 취약하고 제대로 된 민주주의가 부재한 것은 당연할 수밖에 없다. 이러한 방식은 저개발의 원인에서 저개발의 결과를 다시 찾는 오류를 범하고 있을 뿐 아니라 여러 아시아 지역이 이와 비슷한 환경을 가졌었음에도 불구하고 아프리카지역과는 다른 속도로 발전을 꾀하고 있는 점을 고려할 때, 동일한 논리로 아프리카지역의 지속적인 빈곤을 설명하기에는 근본적으로 한계가 존재한다.(박영호 외 2008:47 49)

이에 아프리카지역의 부진한 빈곤개선을 보는 데 있어 보다 다른 시각으로 접근할 필요가 있다. 아프리카지역의 국경선을 살펴보면 유독 다른 지역에 비해 반듯반듯하게 구분되어 있다. 이는 식민지 시절, 유럽 국가들의 아프리카지역에 대한 민족, 언어, 문화, 종교의 다양성이 거의 고려되지 않은 상황 속에서 임의적으로 구분되었기 때문이다. 이러한 이유로 이 지역은 전혀 다른 종족이 한 국가의 범주로 구분되어 끊임없는 갈등을 겪기도 하고 동일한 종족이 다른 국가의 범주로 나누어져 기존의 국가에서 독립을 원하기로 하는 등 60 년 독립 이후 한 국가 내외의 민족 간 갈등이 빈번하게 발생, 유혈사태로 이어지는 등 그 상황이 심각하다. 실제 과거 제국주의의 식민통치에 의해 설정된 아프리카 분쟁지역의 국경은 독립의 시기를 넘어서면서 때로는 국가 간 분쟁의 중요한 원인으로 때로는 물리적 제한된 국가 영역 내에 강제적으로 편입된 이질적 집단 간의 내전을 심화시키는 제한선으로 인식되고 있는데 이로 인해 1980년대 중반의 에티오피아, 19831년 이후의 수단, 1992년 이후의 소말리아, 1994년 이후의 르완다 등은 모두 제한된 국경 내에서의 내전형태의 분쟁을 겪었다(최동주 2006: 364 365)

또한 아프리카지역에서 발생한 주요 분쟁은 아직 해당 이슈가 미결되어 잠재적으로 분쟁의 성격을 지닌 것과 최근 종료된 것까지 합하여 약 44건으로 집계되고 있다. 그리고 이 수치에는 한 국가 내에서 발생한 여러 건의 분쟁이 포함되기도 하여1), 특정 사안이 분쟁 발발에 주요하게 작용하고 있음을 시사하고 있다. 이 유형들을 살펴보면 가시적으로는 주로 자원을 둔 이권다툼, 이질적인 종교 간의 대립 등으로 크게 구분되고 있다. 하지만 그 내용의 이면에는 상이한 종족문화의 다양성이 충분히 고려되지 않은 국가 재건, 통치 등을 공통적으로 내포하고 있다.

그렇다면 유독 아프리카지역이 만성적인 빈곤에서 해방되지 못하는 이유가 이런 배경과 연관이 있는 것은 아닐까? 이에 본고에서는 이 지역에서 고질적으로 개선되지 않는 빈곤의 문제를 갈등, 특히 임의적으로 구분된 국경 선 내에서 이질적인 문화를 가진 종족 간 갈등으로 야기되는 분쟁에 초점을 두고자 한다. 그리고 이 과정에서 전체 아프리카지역을 포괄적으로만 다루어 이론적 접근으로 마무리 하는 대신 대표적인 사례를 보완하여 살펴봄으로써 종족간의 갈등과 빈곤이 어떤 식으로 상호연관성을 지니는지에 대해 분석, 연구를 보다 구체적으로 다룰 것이다. 우선 본고의 핵심 주제인 '종족갈등과 빈곤' 에 대한 개념 정의와 이의 상호연관성에 대한 외부 시각을 살펴보는 것을 시작으로 사하라이남 아프리카지역 전반의 종족갈등과 빈곤 현황을 살펴볼 것이다. 그리고 이어 한 국가의 사례를 분석, 이를 통한 시사점과 이 지역의 빈곤개선을 위해 고려해야할 점으로 본고를 마무리하고자 한다.

1) KIDA, World War Watch 홈페이지 참조 (검색: 2014. 03) 


\section{II. 종족갈등과 빈곤}

\section{1. 개념정의}

\section{1) 갈등인가, 분쟁인가?}

일반적으로 갈등(葛藤)은 개인이나 집단 사이에 목표나 이해관계가 달라 서로 적대시하거나 충돌하는 상태를 뜻하며 분쟁(紛爭)은 이러한 상이한 이해관계를 바탕으로 시끄럽고 복잡하게 다투는 것2)을 의미, 분쟁은 갈등의 원인으로 작용하기도 하고 결과가 되기도 하는 등 갈등과 분쟁은 구분된다. 그러나 영문 상 '갈등'을 의미하는 'Conflict'의 경우, 상황에 따라 다른 단어와 결합하여 '충돌'의 의미로 사용되는 경우도 잦다. 일반적으로 많은 학자들이 아프리카에 관한 연구에서 국가 간에, 혹은 국가에 반하는 무장반란, 쿠테타(Coup d'etat) 등의 내용을 설명할 때 '갈등(Conflict)'으로 표현하여 갈등과 충돌을 혼용하는 경우가 많은데(Abdalla bujra 2000:3), 이는 두 개념이 다소 복잡하게 얽혀있어, 분명하게 구분하기 다소 어려운 점이 있다.

그러나 ‘분쟁'의 개념을 보다 전문적으로 살펴보면 적어도 일방은 하나의 '국가 또는 정부’로 구성되는 2개 이상의 행위자들을 주체로 하여 각각의 존립 또는 번영 등과 직결되는 중대한 이익의 확보라는 쟁점과 목표를 가지고 조직적 무력을 기반으로 비평화적, 비외교적 방법과 수단을 사용, 위협하여 상호간 대립 또는 충돌하는 사태를 통틀어 일컫는다.' 이에 하나의 ‘국가 또는 정부’로 구성되는 일방과 대결하는 의미가 아닌 종족 간의 갈등은 '분쟁'으로 표현하기에는 그 의미가 정확하지 않다. 그러므로 본 논문에서는 종족 간 상이한 이해관계를 바탕으로 시끄럽고 복잡하게 다투는 내용에 있어서 '분쟁' 이라는 개념이 아닌, '갈등'으로 명기하고 정부와 대립하는 양상의 '갈등'의 경우에만 '분쟁'으로 표기하고자 한다.

\section{2) 빈곤}

빈곤에 관해서는 다양한 정의가 있지만 일반적으로 사람이 생활하는데 필요한 것을 갖추지 못한 상태를 의미하며 과거에는 이것이 식생활 위주의 불충분함, 혹은 경제적인 궁핍만을 뜻하였다. 그러나 현대에는 실제 생활속에서 발생하는 빈곤이 노동과 교육기회로 부터의 소외, 건강하지 않음, 여러종류의 서비스, 자원, 기술에 대한 접근 기회 부족 등 복잡하게 연결되어 나타나는 점을 고려하여 다차원적인 개념으로 접근하고 있다. 경제협력개발기구(OECD:Organization for Economic Cooperation and Development)의 경우, 현대의 빈곤을 대략 5가지 능력이 결핍된 것으로 보고 있는데 여기에는 물질을 소비하고 소유할 수 있는 경제 능력(economic capabilities), 안전한 식수, 건강 등 생활개선을 위한

2) 국립국어원. 표준국어대사전 검색(검색: 2014. 04)

3) KIDA, World War Watch 홈페이지 참조(검색: 2014. 04) 
핵심요소인 인적능력(human capabilities), 인권 및 발언권 같은 정치능력(political capabilities), 지역사회에서 의미 있는 구성원으로 참여 가능한 사회·문화능력(socio-cultural capabilities), 경제 및 외부 충격으로부터 견딜 수 있는 보호능력(protective capabilities)등이 포함된다(OECD 2001:38).

또한최근들어서는 빈곤선(povery line $)^{4)}$ 의 개념을 국제적으로 통용하여 세계의 상황을 보다간단하게 비교하기도 한다. 이외, 빈곤과 관련된 계량화된 지수로는 다차원적 빈곤지수(MPI: Multidimensional Poverty Index)와 ‘삶의 질 지수’라고도 불리는 인간개발지수(HDI: Human Development Index)가 있는데, 다차원적 빈곤지수의 경우 10 개의 지표를 혼합하여 사용하다 보니 지표가 누락되어 전체 값 측정이 되지 않는 국가가 자주 발생, 아직까지 아프리카지역 국가들의 자료가 불충분한 편이다. 반면 인간개발지수의 경우, 사용지표가 '평균수명', '교육수준'과 ' 1 인당 소득'으로 지표가 간단한 데 비해 인간개발의 성취정도 및 사회적 의미의 인간다운 생활수준을 복합적으로 잘 드러내어 인간 삶의 질 수준의 국가 간 비교에서 자주 사용되고 있다(권유경 2013:19 34). 이에 본 논문에서는 빈곤의 변화를 다루는 내용에 있어서는 분석의 기준으로써 인간개발지수(HDI)를 삼고자 한다.

\section{2. 종족갈등과 빈곤을 보는 시각}

\section{1) 종족갈등의 주요 원인과 특징}

아프리카는 다른 어떤 지역보다도 종족적 다양성을 지니고 있어 한 국가 내에서 전체 인구의 수는 적을 지라도 종족의 분류는 대단위로 나타나는 경우가 많다. 이에 많은 아프리카 국가들은 강한 정체성을 띄는 다중집단(multiple group)이 존재하고 이는 다양한 이해관계의 상충으로 인해 통합을 어렵게 만드는 원인이 되기도 한다(Abdalla Bujra 2000:15). 특히 종족 간의 상이한 정치적 입지에 따라 발생하는 경제활동 참여기회의 차별은 공적영역의 직업분배, 각종 자격증 취득 제한, 불균등 계약조건, 편파적 세수정책, 뇌물 공여 과정, 투자조건 차별화 등 제도적으로 구조화되어 나타나기도 한다. 이러한 차별화되거나 제한적으로 적용되는 각종 사회규범이나 제도는 중장기적으로 볼 때 물리적인 갈등의 배경이 되었다(Azam and Morrison 1999, 재인용: 최동주 2006:378).

게다가, 최근 다이아몬드, 석유와 같은 아프리카의 천연자원의 분배과정에서 발생하는 불평등은 이러한 갈등을 더욱 증폭시킨다. 자원은 종족 간에 지정학적(geo-economic) 위치 확보를 위한 다양한 원인을 제공하며 자원의 확보는 곧 정치 사회 권력의 확보를 위한 물리적 기반을 제공하기 때문에 경쟁은 치열하며 자원 확보의 기회를 상실한 세력은 항상 신분의 전환과 상승을 위해 노력할 수밖에 없다. 또한 천연자원은 곧 지리적 위치에 삶의 기반을 둔 종족의 직업을 결정하는 수단으로 작용하기 때문에 경제적 개방에 따라 산업이 차별화되거나, 생산품 가치의 경제적 차별이 발생할 경우 갈등의 원인이 된다. (최동주 2006:379)

4) 빈곤선(poverty line)이란 영국의 사회학자 벤저민 라운트리(Benjamin S. Rowntree)가 제시한 개념으로 신체적 효율성을 유지할 수 있는 최소한의 범위를 담고 간신히 생계를 유지하는 수준을 드러내기 위해 사용된 것 김영모 편, 1992:142)으로 최근에는 하루 평균 1.25 달러를 그 기준으로 삼고 있다. 
더불어 종족 간 대립되는 종교문화를 가지고 있을 경우, 갈등의 잠재요인으로 작용할 수 있다. 2013 년 한 해 동안 아프리카의 ‘이슬람' 세력들은 무장단체는 물론 정치조직, 심지어 개인 혹은 마을 공동체 단위로 이슬람이라는 정체성에 기반, 유혈 충돌의 중심에 섰다 ${ }^{5}$. 한 국가 내에서 상이한 종교문화를 주로 내세워 대립과 갈등을 일으키는 사례는 몇몇 국가에 한정적인 편이다. 하지만 지역에 따른 연고, 정치력의 차이, 경제적 이권다툼들이 혼합적으로 작용하여 갈등과 긴장상태를 지속시키는 주요 원인으로 작용하기도 한다. 즉, 아프리카 지역에서 종족 갈등은 특정 종족이 상대 종족에 대한 정치, 경제적 우위를 점하는 경우 이해관계 상충으로 인한 충돌을 불가피하게 만드는데, 이는 상이한 종교문화를 기반으로 하는 경우, 물리적인 충돌을 야기하지 않더라도 갈등과 긴장상태를 유지하는 것이다.

\section{2) 빈곤과 종족갈등}

빈곤은 전통적으로 개발학, 인류학, 경제학의 주요 화두로 대두되었던 반면 갈등은 주로 국제관계나 정치사회적 개념에서 다뤄져왔다. 그러나 최근 들어 이 둘의 개념을 접합시킨 논의가 늘어나고 있다 (Jonathan Goodhand, 2001:12). 빈곤과 갈등의 관계에 관해서는 한 개인이 타인에 비해 자신이 박탈된다고 생각하는 인식이 자신이 속한 그룹이 아닌 다른 그룹에 대해 적대감을 지니게 한다는 상대적 결핍이론(Relative Deprivation Theory)'을 고려해볼 수 있다. 이는 종종 자신이 속한 그룹의 상황이 상대 그룹에 비해 비교적 더디게 개선된다고 인지할 때 더욱 강하게 나타나는데 이는 상대에 대한 편견과 사회저항과도 밀접하게 연관된다. 이 이론은 주로 아프리카지역에서 빈곤과 갈등의 관계를 설명할 때 자주 사용되는데 체계적이지 않은 정부시스템과 경제자원에 대한 불공정한 접근 및 분배의 상황은 특정 집단이 타 집단에 비해 보다 쉽게 기회 획득에 있어서 우위를 점하게 만든다. 이는 안정적 사회망 구축에 있어 특정 그룹 사이에서의 빈곤을 지속하게 만들 수 있고 경제 뿐 아니라 권력관계에 있어서도 불평등한 결과를 가져오게 할 수 있다(Rasheed 2003:9).

게다가 이러한 갈등은 직 · 간접적인 비용을 동반하게 된다. 폭력을 수반한 갈등은 직접적으로는 전장에서의 죽음, 장애를 가져 오게 하고 이로 인한 전체인구 중 노인, 여성과 장애인의 비율 증가는 인적자원의 성장을 어렵게 하여 빈곤의 만성화를 야기하기도 한다. 특히, 보건, 교육과 같은 서비스 제공이 원활하지 않은 것은 인구의 기대수명 감소, 문맹률을 증가시켜 개발의 필수적인 인적자원의 성장을 방해할 뿐 아니라 시장의 감소, 자금의 부족 등과 같이 경제를 위축시킴으로써 국가 발전에 영향을 미친다(Jonathan Goodhand 2001:13 14). 실제 World Bank에서 조사한 결과, 아프리카에서의 갈등과 분쟁은 대륙 전체의 매해 경제성장률을 $2 \%$ 감소시키는 결과를 낳기도 하여 경제적 측면의 빈곤과의 연계성이 높았다(DFID 2001:11, 재인용: Jonathan Goodhand 2001:14). 더불어 아프리카지역에서 청년층의 성장은 이러한 빈곤-갈등의 관계를 더욱 강하게 만드는 새로운 변수로 작용할 수 있다. 최근 부족한 인프라 상황 속에서 급증하는 인구 추세는 한 집단이 타 집단에 비해 상대적인 박탈감에 대해 보다 쉽게 인지할 수 있도록 만들 수 있다. 특히 청년층의 경우 다른

5) KIDA, World War Watch 홈페이지 참조(검색일: 2014. 04) 
연령대에 비해 반란에 가담할 가능성이 상대적으로 높아, 청년층에서 종족간의 대립은 사회의 안전망에 더욱 위험하게 작용할 수 있고(Rasheed 2003:10) 치안의 불안정은 안정된 성장을 방해, 빈곤개선을 더디게 만든다.

특히 종족 갈등의 경우 국가적 분쟁의 양상으로 커지지 않는 이상 지역화 되어있는 특성이 강한데, 이럴 경우 기초 데이터 확보가 어렵고 이로 인해 빈곤과의 관계를 양적 데이터로 직접 규명하기에는 어려움 점이 있는 것이 사실이다. 그러나 앞서 살펴본 바대로 다양한 종족성이 아프리카지역에서 빈번한 갈등을 설명하는 핵심 요소로 공통적으로 작용하고 있는 것은 분명하다. 종족성은 아프리카에서 일어나는 모든 갈등에 사실상 기초로 작용하고 있는데 재산권, 직업, 교육, 사회시설과 같은 핵심 자원에 대한 종족 간의 대립이 강해질수록 갈등은 심각해지는 양상을 나타낸다(Brian-Vincent 2009:17). 즉, 다시 말해, 종족 간의 갈등은 빈곤한 상황에서 한정된 자원을 두고 더욱 강해지는 특성을 나타내기도 하고 체계화되지 않은 국가 체제 속에서 종족간의 갈등이 빈곤을 더욱 만성적으로 만들기도 하는 것이다.

\section{III. 사하라이남 아프리카지역의 종족갈등과 빈곤}

\section{1. 종족갈등 현황과 특성}

사하라이남 아프리카지역에서 발생하는 갈등은 다양한 종족간의 상이한 문화를 배경으로 종교, 자원 등이 복합적으로 얽혀 발생하고 있다. 이 중에서도 한 국가 내에서 종족을 기반하여 상충된 이해관계로 발발한 주요 갈등의 현황을 파악해보면 다음과 같다(표 1 참조).

$<$ 표 1> 사하라이남 아프리카지역의 종족 간 발생한 주요 갈등 현황(1960 2013)

\begin{tabular}{|c|c|c|c|}
\hline 순번 & 국가 & 원인 & 현황 \\
\hline 1 & 나이지리아 & $\begin{array}{l}\text { 출신지역, 상이한 종교문화, 경제적 이익이 복합적 } \\
\text { 으로 작용 }\end{array}$ & $\begin{array}{l}\text { 1999년 발생 } \\
\text { - 현재 미종료 }\end{array}$ \\
\hline 2 & 말리 & 중앙 강압정책에 대한 지방부족의 반발 & $\begin{array}{l}\text { 1980년 발생 } \\
\text { - 현재 미종료 }\end{array}$ \\
\hline 3 & 케냐 & $\begin{array}{l}\text { 켄야타(Kenyatta) 대통령의 서거로 그 자리를 승계한 } \\
\text { 모이(Moi) 대통령과 그의 집권에 반발하는 부족들 } \\
\text { 간에 발발 }\end{array}$ & $\begin{array}{l}\text { 1978년 발생 } \\
\text { - 현재 미종료 }\end{array}$ \\
\hline 4 & 에티오피아 & $\begin{array}{l}\text { 종족 구성을 무시한 식민종주국의 영토 확정 및 } \\
\text { 합병에 기인한 종족 간 분쟁 }\end{array}$ & $\begin{array}{l}\text { 1962년 발생 } \\
\text { - 현재 미종료 }\end{array}$ \\
\hline
\end{tabular}




\begin{tabular}{|c|c|c|c|}
\hline 순번 & 국가 & 원인 & 현황 \\
\hline 5 & 수단-남수단 & $\begin{array}{l}\text { 북부지역 아랍계 무슬림과 남부지역 기독교 부족 } \\
\text { 간의 갈등 }\end{array}$ & $\begin{array}{l}\text { 1983년 발생 } \\
\text { - 현재 종료, 분쟁의 잠재성 강함 }\end{array}$ \\
\hline 6 & 토고 & $\begin{array}{l}\text { 카베야(Kabeya)족 출신 에야데마(Eyadema) 대통령의 } \\
\text { 독재와 이에 반발한 에웨(Ewe)족 중심의 재야세력과 } \\
\text { 의 갈등에서 발발 }\end{array}$ & $\begin{array}{l}\text { 1963년 발생 } \\
\text { - 현재 미종료 }\end{array}$ \\
\hline 7 & 차드 & $\begin{array}{l}\text { 남부 출신 기독교와 북동부 출신 이슬람 세력 간의 } \\
\text { 갈등 }\end{array}$ & 1966년 발생, 종료 \\
\hline 8 & 가나 & $\begin{array}{l}\text { 국가통치권을 둘러싼 중앙정부와 지방부족 세력인 } \\
\text { 에웨(Ewe)족 간의 갈등 }\end{array}$ & 1966년 발생, 종료 \\
\hline 9 & 니제르 & $\begin{array}{l}\text { 식민지적 영토 확장과 이에 따른 종족차별로 인한 } \\
\text { 갈등 }\end{array}$ & 1960년 발생, 종료 \\
\hline 10 & 르완다 & $\begin{array}{l}\text { 투치족과 후투족간의 국가통치권 쟁취를 둔 유혈 } \\
\text { 분쟁 }\end{array}$ & 1990년 발생, 종료 \\
\hline 11 & 부룬디 & 투치족과 후투족간의 정권탈취를 둘러싼 대립 & 1992년 발생, 종료 \\
\hline 12 & 지부티 & $\begin{array}{l}\text { 이싸족에 의한 권력 집중 이에 발탈감과 불만이 증폭 } \\
\text { 된 아파르족 간의 갈등 }\end{array}$ & 1991년 발생, 종료 \\
\hline 13 & 라이베리아 & $\begin{array}{l}\text { 미국에서 해방된 소수 흑인 노예 출신과 기존흑인 } \\
\text { 원주민들과의 갈등 }\end{array}$ & 1989년 발생, 종료 \\
\hline
\end{tabular}

출처: KIDA, World War Watch 홈페이지 '아프리카 분쟁' 내용을 참고하여 저자 작성

<표 1>에서 살펴본 바대로 사하라이남 아프리카지역 총 48 개 국가 중, 종족 간의 갈등을 바탕으로 하여 발생한 충돌, 분쟁은 약 13 건으로 집계되었다. 이들 중에는 종료된 건도 존재하지만 아직까지 잠재적인 충돌의 위험을 내포하고 있거나 현재까지 진행되고 있는 것도 상당하다. 상기와 같은 갈등을 겪었거나 겪고 있는 국가들은 이미 그 갈등의 과정에서 상당한 인명 피해 및 기반 시설의 파괴 등을 경험하였다. 그러나 문제는 최근 들어 종족을 중심으로 한 공동체 간 유혈 충돌이 종식되거나 약화되기보다는 경제적 이권 다툼, 주요 자원 생산지의 영토 차지 등의 이슈와 맞물려 증가하고 있다는 것이다. 또한 예전에 종족 간의 갈등으로 대립에서 그치던 양상이 점차 무장 조직화되고 정부와 대립하면서 분쟁의 성격을 나타내고 있으며 이 지역의 치안상황을 전반적으로 더욱 악화시키고 있다.

최근 급속한 세계화의 진행으로 인해 국가주도형 경제발전보다는 개방형 경제의 선택이 경제적 빈곤상태로부터의 유일한 돌파구라는 경제정책 결정자들의 인식이 확대되면서 개방형 시장경제를 추구할 수밖에 없는 상황에 처한 정부 측은 경제적 인센티브를 통해 이러한 저항세력들을 설득하려하고 있다. 그러나 이 과정에서 여전히 불균등한 분배와 공유가 보이지 않는 시장의 권력과 집단의 주도하에 갈등은 증폭되고 있기 때문에 갈등 해결의 실마리는 쉬이 보이지 않는 실정이다(최동주 2006:365). 


\section{2. 빈곤 현황 및 내용}

전 세계적으로 빈곤 감소를 위해 노력하고 있는 가운데 개발도상국에서 1990년대 하루 1.25 달러 미만의 생활자는 약 20억명이었으나 2008년에는 약 14억명 수준으로 크게 감소하였다(UN 2012:7) 그러나 여전히 세계의 많은 인구가 배고픔에 고통받고 있으며 영양실조가 심각한 가운데 특히 사하라이남 아프리카지역은 영양실조가 전 국민 평균 $35 \%$ 이상을 상회하는 국가와 $25 \sim 34 \%$ 에 속하는 국가가 대부분이다(그림 1 참조).

\section{<그림 1> 2005년 2007년간 전세계 영양실조 인구 분포}

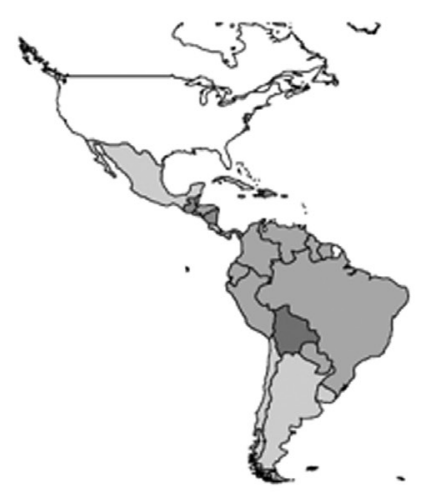

Very high (undernourishment $35 \%$ and above) High (undernourishment 25-34\%)

Moderately high (undernourishment $15-24 \%$ )

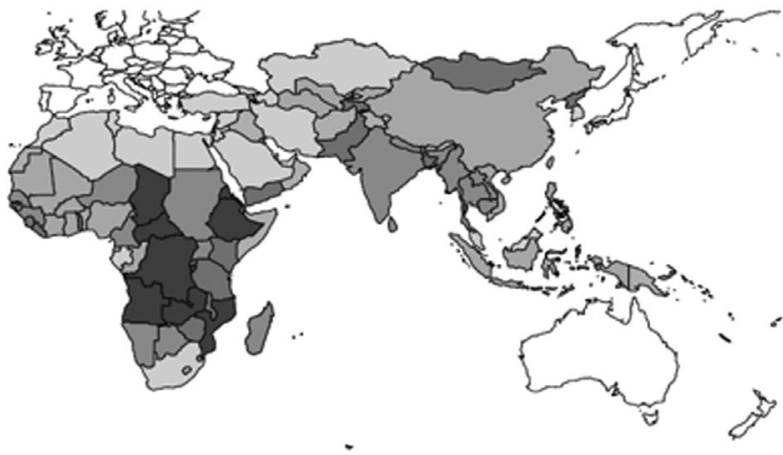

Moderately low (undernourishment 5-14\%)

Very low (undernourishment below $5 \%$ )

Missing or insufficient data

출처: UN 2011:12

또한 이 지역의 경우 빈곤선인 하루 1.25달러 미만 생활자가 1990년대 56\%에서 2010년 48\%로 크게 감소한 듯 보이나 인구 증가로 인해 절대 숫자는 더욱 늘었다(UN 2013:6 7). 그리고 1달러 미만의 생활자는 줄었으나 1.25 2달러 이하의 생활자는 크게 줄어들지 않아 빈곤의 상황은 거의 개선되지 않았음을 알 수 있다(UNECA et al. 2012:2). 더욱이 세계의 10대 취약 식량빈곤국) 중 한 국가를 제외하고 모두 아프리카 국가로 이 지역의 빈곤상황이 타 지역보다 매우 심함을 확인할 수 있다.

기초교육에 대한 접근은 전 세계 개발도상국 평균 1990년대 80\%에서 2011년 90\%로 진전을 보였으나 사하라이남 아프리카지역은 2011년 77\%에 머물러 이 분야 또한 역시 열악하다. 5세 이하 아동사망률 또한 많은 국제기구들의 사회부분에 대한 원조로 인해 1990년 1,000명당 89명이 사망했었으나 2009년 60명 수준으로 상황이 매우 호전되었으며 가난한 가정의 아동은 부유한 가정의

6) Africa progress panel 보고서에 따르면 세계의 10대 취약 식량빈곤국으로는 (1)Afghanistan, (2)DR congo, (3)Brundi, (4)Eritrea, (5)Sudan, (6)Ethiopia, (7)Angola, (8)Liveria, (9)Chad, (10ZZimbabwe로 아프가니스탄을 제외하고는 모두 아프리카 국가이다(APP 2011:40) 
아동보다 사망할 확률이 약 3 배 높은 것으로 나타났다. 북아프리카와 동아시아에서 가장 높은 감소율을 보였으며 사하라이남 아프리카는 180 명에서 129 명으로 줄었으나 이는 선진국의 약 18 배 높은 수치로 아직 이 부분에 대한 개선이 상당히 요구된다. 전반적인 보건 상황에 있어서도 많은 개발도상국에서 상황이 진전되었다. HIV(Human Immunodeficiency Virus)의 경우, 이에 감염된 사람들은 2009년 약 3,300만정도로 이것은 1999 년보다 $27 \%$ 가량 증가한 수치이다. 하지만 이 중 약 $69 \%$ 가 사하라이남 지역에 거주하고 있으며 이들 대부분은 HIV에 대해 알지 못하는 실정이다. 특히 여성과 젊은 층이 $\mathrm{HIV} / \mathrm{AIDS}$ 에 취약7)하여 경제성장의 기반이 되는 건강한 인적자원의 부족을 겪고 있다.

여기에 또한 주목해야할 특성이 있다. 사하라이남 아프리카지역은 타 지역에 비해 청년층(youth)의 구성 비율이 월등히 높으며 이러한 추세는 점점 더 강해질 전망이다 (그림 2 참조).

$<$ 그림 2> 아프리카 청년층(15 24세)의 타지역과의 비교

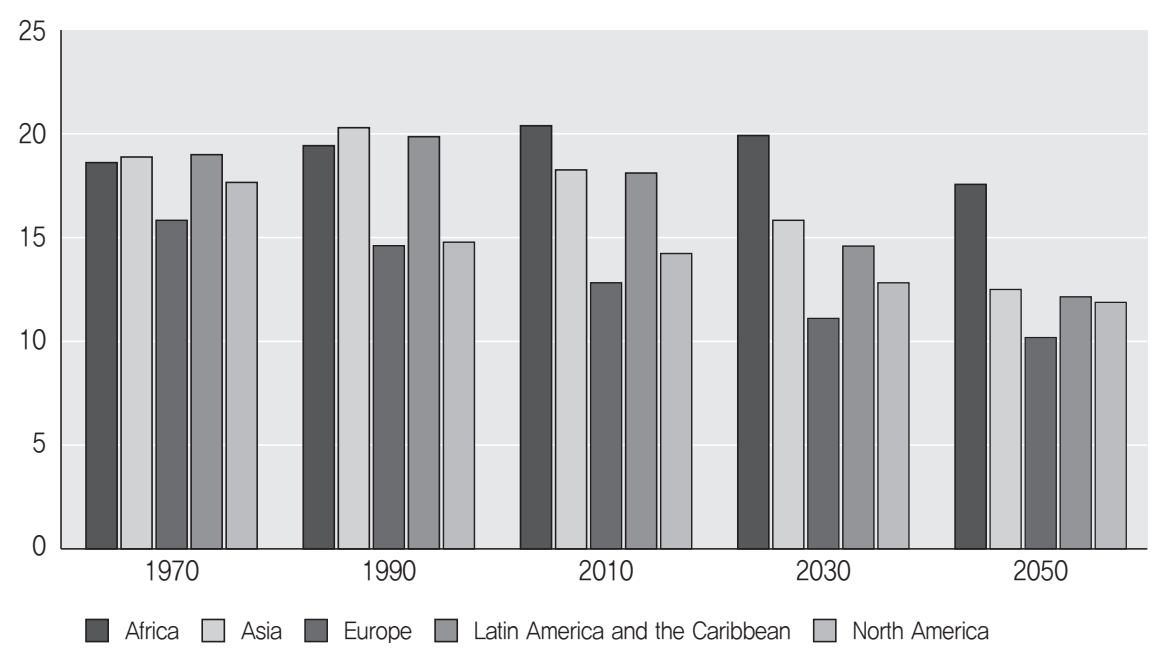

출처: UNECA 2011:9

그러나 이 지역에서 소득 창출을 위해 국민들이 가질 수 있는 1 차 산업에 집중된 산업구조로 인해 직업의 분포는 꽤 한정적인데, 국가의 소득 수준이 Low income일 경우 $69.4 \%$ 가, Low-middle income일 경우 55.1\%가 농업에 관계한다(Deon Filmer et al. 2014:35). 그러나 낮은 생산성으로 인해 소득 창출이 어려우며 이 지역 내에서 점차적으로 후퇴하고 있는 분야에 속한다. 실제, 가나, 나이지리아, 르완다, 탄자니아, 우간다에서 성장하고 있는 고용구조는 농업보다는 Private wage와 $\mathrm{HE}$ (Household and medium-size enterprises)로 옮겨가고 있다(그림 3 참조).

7) 사하라이남 아프리카지역의 경우 HIV와 관련한 지식이 청소년층(15 24세)사이에서 매우 낮은 편이었는데 HIV 전이에 대한 지식을 조사한 결과, 여성 평균 $26 \%$ 만이, 남성 평균 $35 \%$ 만이 그와 관련한 사실을 알고 있어 상대적으로 여성은 이와 관련한 정보 획득에도 불평등을 겪고 있는 것으로 나타났다(UN 2012:40). 


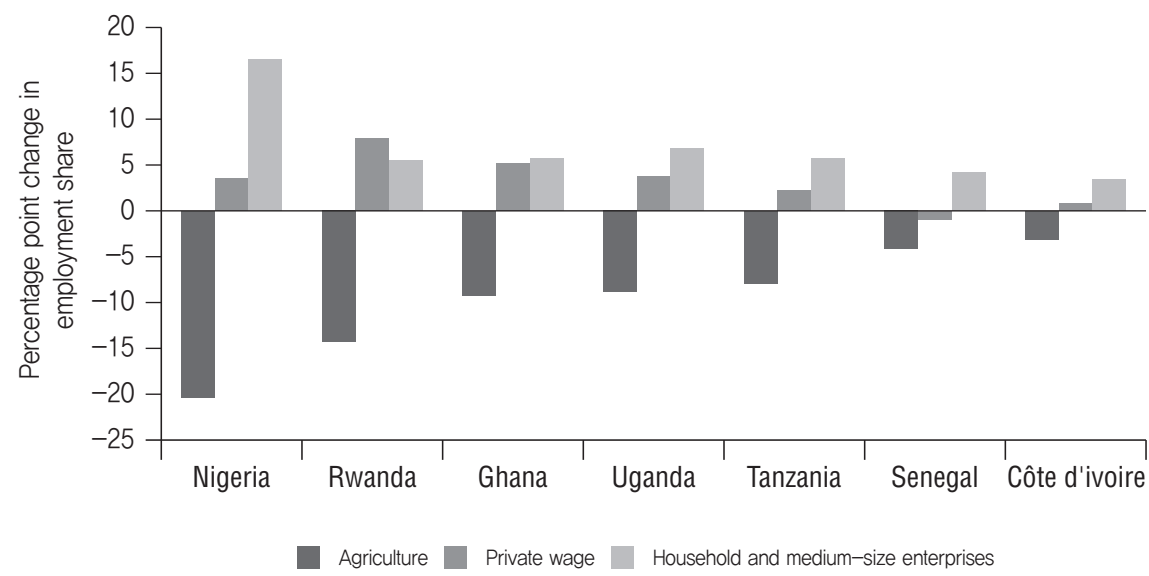

출처: Deon Filmer et al. 2014:33

직업은 단순히 소득창출을 넘어서서 인간의 정체성을 실현하고 사회와 상호작용하게 하여 국가의 전반적인 경제성장을 이끌어내는데 매우 중요하다. 게다가 상이한 종족, 젠더 등과 같은 다른 배경을 가진 사람들과 상호작용하게 하고 네트워킹 하게함으로써 사회 전체를 발전시키는 측면도 있다. 실제 르완다의 커피농장 사례에서 상이한 종족 간의 공동 작업은 상대 종족의 문화를 더 잘 이해하게 만들어 서로간의 불신을 감소시켰다(Tobias and Bouderaux 2011, 재인용: Deon Filmer et al. 2014:43). 그러나 산업구조의 변화가 증가하는 인구의 속도를 맞춰가기에는 무리가 있어 아프리카지역의 많은 청년층이 소득창출과 연관된 직업을 갖기는 어려운 실정으로 청년층들이 고용에서 제외되는 것이 장기적으로 진행될 경우, 사회의 안정성에 심각한 영향을 미칠 수 있다.

\section{3. 종족갈등과 빈곤의 연관성}

'삶의 질'을 전반적으로 비교할 수 있는 인간개발지수(HDI)를 살펴보면 아프리카지역은 타 지역에 비해 전 영역에서 모두 취약할 뿐 아니라 세계 평균에서도 상당히 뒤처지고 있다(표 2 참조)

$<$ 표 2> 세계 지역별 HDI 비교

\begin{tabular}{l|r|r|r|r|r}
\hline \multicolumn{1}{c|}{ 지역 } & \multicolumn{1}{|c|}{$\mathrm{HDI}$} & 기대수명 & 교육 평균년수 & 교육 예상년수 & 1인당 GNI \\
\hline Arab states & 0.652 & 71.0 & 6.0 & 10.6 & 8.317 \\
\hline East Asia and the Pacific & 0.683 & 72.7 & 7.2 & 11.8 & 6,874 \\
\hline Europe and Central Asia & 0.771 & 71.5 & 10.4 & 13.7 & 12,243 \\
\hline Latine America and the Caribean & 0.741 & 74.7 & 7.8 & 13.7 & 10,300 \\
\hline South Asia & 0.558 & 66.2 & 4.7 & 10.2 & 3,343 \\
\hline
\end{tabular}




\begin{tabular}{l|r|r|r|r|r}
\hline \multicolumn{1}{|c|}{ 지역 } & HDI & 기대수명 & 교육 평균년수 & 교육 예상년수 & 1인당 GNI \\
\hline Sub-Saharan Africa & 0.475 & 54.9 & 4.7 & 9.3 & 2,010 \\
\hline World & 0.694 & 70.1 & 7.5 & 11.6 & 10,184 \\
\hline
\end{tabular}

출처: UNDP 2013:25

그럼 1990년과 2013년 사이 종족간의 갈등이 발생했던 국가의 인간개발지수는 어떨까? 최근까지 종족갈등이 미종료 되었거나, 종료된 듯 보이나 갈등의 잠재성이 농후한 국가(표 1 참조)까지 6 개국의 인간개발지수(HDI)를 비교해본 결과 케냐 한 곳을 제외하고는 모든 국가들이 사하라이남 아프리카지역의 평균인 0.475 보다도 그 수치가 낮았다(그림 4 참조).

$\mathrm{HDI}$

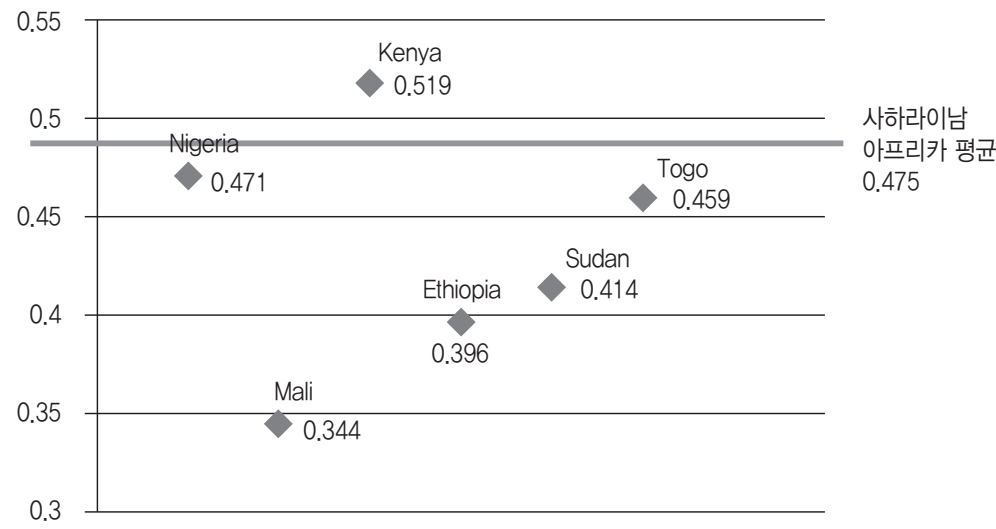

출처: UNDP 2013을 참조하여 저자 작성

실제 1990년 이후 무력분쟁이 주로 발생한 지역은 HDI가 가장 낮은 10 개국 중 9 개국이었는데 유엔개발계획 자료에서 개발지수가 낮다고 파악된 전체 국가의 $2 / 3$ 가 최근 15 년간 일어난 내전의 무대가 되었다고 한다. 통계적으로도 개발도상국의 경제성장률이 $5 \%$ 떨어질 때마다 그곳에서 갈등이 일어날 개연성은 $50 \%$ 나 더 높아지고 있는데 이를 통해 빈곤이 갈등 혹은 분쟁을 낳고 이는 빈곤을 증폭시키는 등 빈곤과 분쟁은 서로 밀접하게 연관되어 있다고 볼 수 있다(카를-알브레히트 이멜, 2009:302 304, 재인용: 권유경 2013:31).

빈곤을 유발하는 여러 가지 조건과 상황들을 고려할 때 종족갈등이 빈곤과 가지는 직접적인 연관성을 언급하기에는 무리가 있다. 그러나 최근까지 갈등의 양상을 보인 6개국의 인간개발지수가 사하라이남 아프리카지역의 평균보다도 낮다는 것은 종족갈등이 빈곤과 무관하지 않다는 것을 잘 보여주고 있다. 이에, 6 개국 중의 하나인 나이지리아의 사례를 통해 종족갈등이 빈곤과 가지는 연관성에 대해 보다 상세히 알아보고자 한다. 


\section{IV. 나이지리아 사례 분석}

\section{1. 왜 나이지리아인가?}

\section{1) 나이지리아의 경제 · 사회 특징}

나이지리아는 세계 10 위의 원유 매장량을 보유하고 있으며 광대한 토지와 천연가스, 석탄, 주석 등의 풍부한 지하자원을 바탕으로 향후 중동을 대체할 수 있는 새로운 에너지 공급처로 주목받고 있다. 뿐만 아니라 국제원유의 지속적인 상승과 더불어 연 $6 \%$ 이상의 성장을 지속하며 아프리카에서 가장 많은 인구를 지녀, 경제성장의 잠재력 또한 매우 큰 편이다(외교통상부 2011:43 44).

그러나 이와 같이 발전의 가능성이 풍부한 환경에도 불구하고 1960년 독립 이후 수차례에 걸친 쿠테타와 정치 · 사회적 혼란, 지도층의 부패 등으로 인해 성장의 발판을 마련하지 못한 채 빈곤한 상황에 머물고 있다. 이는 2000년대 들어 고유가에 따른 원유 수입 증가, 원유 생산 확대, 그리고 이를 바탕으로 한 정부의 의욕적인 경제개발 정책을 통해 회복하려는 움직임을 보이며 물가상승률과 더불어 나이지리아 정부는 높은 재정 수익을 올렸다. 하지만 이러한 노력에 반해, 일반 국민들의 전반적인 생활 개선에는 큰 영향을 미치지 못했다(박영호·허윤선· 심자용 2008:3 6).

여기에는 석유산업에 편중된 산업구조, 정부의 부정부패 등의 이유와 더불어 종교, 종족 등의 여러 이해관계 간의 충돌로 인한 치안 불안정이 주된 이유로 지적되고 있다. 또한 나이지리아는 근래 조금 떨어지긴 했으나 최근 5년간(2008 2012년) 연 평균 10\% 이상의 물가상승률을 기록8)하고 있는데, 이는 빈곤 개선을 더욱 어렵게 만들고 있다. 그리고 나이지리아의 실업률을 2011년 기준 약 $23.9 \%$ 로 높은 편인데 연 $2 \%$ 에 가까운 인구성장률과 더불어 청년층의 실업은 사회의 주요문제가 되고 있다. 청년 실업층의 경우 열악한 사회환경으로 인해 기본적인 권리를 보장받지 못할 경우 다른 폭력행사의 경험이 있는 민중 세력과 결합하여 저항과 반란 운동을 주도하는 경우가 쇄도 하고 있다. 이처럼 높은 비율로 성장하고 있는 청소년층에 대한 교육 및 고용이 장기적으로 제공되지 않을 경우, 이들을 중심으로 한 종교, 정치적 과격주의가 확산될 가능성이 높아지고 이는 나아가 정세불안의 잠재적인 요인으로 작용할 여지가 있다(정부부처 합동문서 2013:12 13).

\section{2) 나이지리아의 종족구성과 문화적 특징}

나이지리아는 250 개 이상의 종족, 36 개 주의 연방체제로 구성되어 있으며 역사적으로 종교와 종족의 상이한 배경으로 인해 강한 분권체제의 통일된 중앙집권적 정책집행에 어려움을 겪고 있다. 여러 종족 중에서도 특정 지역을 중심으로 크게 4 개로 구분되는데 북부지역을 기반으로 하며 전체의 약 $29 \%$ 를

8) 나이지리아의 물가상승률 변화: $10.9(2008) \Rightarrow 12.6(2009) \Rightarrow 13.9(2010) \Rightarrow 11.0(2011) \Rightarrow 12.1(2012) \Rightarrow 8.8(2013)$ (Central bank of Nigeria, Data \& Statistics 검색 (검색일: 2014. 04)) 
차지하고 있는 하우사-풀라니족( Hausa-Fulani), 남서부지역을 주거지로 전체의 약 $21 \%$ 를 차지하는 요루바족(Yoruba), 전체의 $18 \%$ 를 차지하는 남동부지역의 이보족(Igbo), 대략 $10 \%$ 를 구성하고 남남부와 유전지대를 근간으로 생활하는 이자우(Ijaw)족이 있으며(그림 5 참조), 종교적으로는 크게 무슬림을 중심으로 하는 북과 기독교를 중심으로 하는 남으로 나뉜다.

\section{$<$ 그림 5> 나이지리아의 주요 종족 분포}

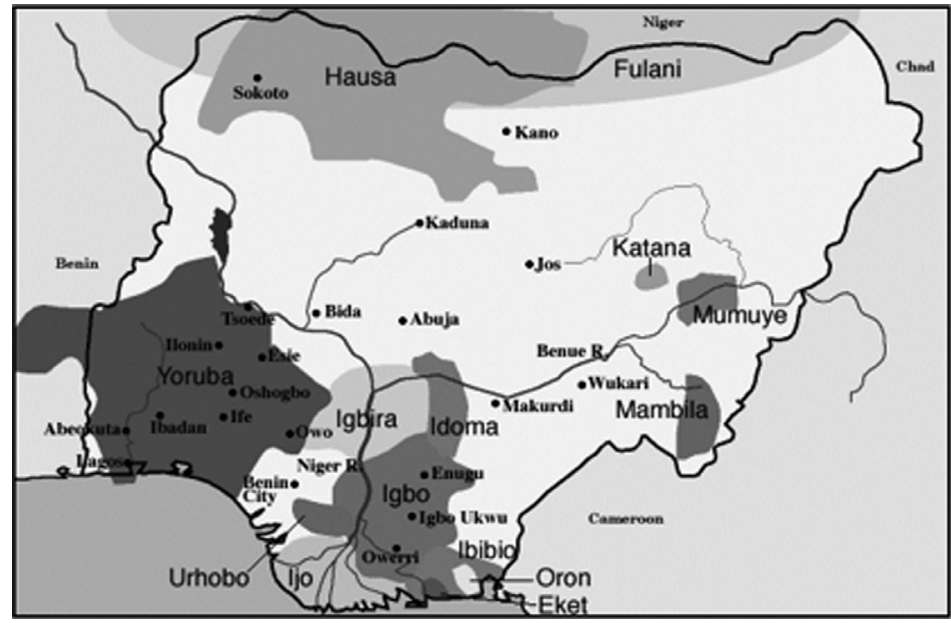

출처: Google 이미지, Nigeria tribes map ${ }^{9}$

이들은 종족적인 구분 뿐 아니라 생활환경, 역사적 경험들이 매우 상이하며 종교적인 배경 또한 달라 충돌이 빈번한 편이다. 북부의 경우 사막성 기후 아래 주로 목축업을 하고 지내오며 9세기 이후 Bornu 왕국에 이어 19세기에 Fulani 대제국을 건설하는 등 강력한 국가 성립과 발전을 이루어오며 이슬람교를 신봉해왔다. 반면, 남부는 해안가를 중심으로 겨울철 우기에만 주로 농업을 하며 17 18 세기 경 노예로 팔려가거나, 북부지역에 대비, 여러 종족이 모여 있어 종족 기반의 강한 정치적 구심점을 북쪽에 비해 상대적으로 가지지 못했으며, 기독교가 대부분이었다(정부부처 합동문서 2013: 4 5 ; 외교부 2011:18 19). 이와 같이 다른 생활환경, 역사적 경험, 상이한 종교를 바탕으로 이질적인 문화를 형성해왔고 이에 나이지리아 내에서도 본인들은 한 국가의 국민이 아니라는 과감한 애기가 거침없이 나오는 등 갈등이 상존할 수밖에 없는 이유를 아예 다른 국민성에서 기인하고 있다고 당연시 한다. ${ }^{10)}$

9) Google 이미지, Nigeria tribes map(검색: 2014. 04)

10) 요루바족의 지도자이면서 저명한 정치가였던 오바페미 아올로오(Obafemi Awolowo)는 나이지리아의 상이한 문화적 배경과 이질감에 대해 “나이지리아는 국가가 아니다. 단지 지리적인 표현일 뿐이다. 영국인, 프랑스인과 같은 의미에서 나이지리아인은 없다. 나이지리아인이라는 말은 단지 나이지리아라는 영토 내에 살고 있는 사람들을 그렇지 않은 사람들로부터 구분하기 위한 지시적 호칭에 불과하다" 라고 발언한 바 있다. (외교통상부 2011:67) 


\section{2. 나이지리아 종족갈등}

\section{1) 갈등형성의 원인}

나이지리아는 전체 인구의 $50 \%$ 가 이슬람교, $40 \%$ 가 기독교, 기타 $10 \%$ 정도가 전통 신앙으로 구성되어 있는데 ${ }^{11)}$ 기독교와 이슬람교 또한 단일 교리가 아니라 여러 종파와 분파로 나누어져 있는 실정이다. 종교분선은 크게 남과 북으로 구분이 되는데 종족 단위로 동일한 종교를 가지고 있다는 점과 특정 지역을 기반으로 한 종족 간의 갈등이 지속적으로 나타나는 점을 고려할 때 종족 갈등과 분리하여 생각할 수가 없다.

종교 간의 대립은 1980년 중반 이후 기독교도들이 무하마두 부하리(Muhamadu Buhari)와 이브라힘 바방기다(Ibrahim Babangida) 군사정권의 이슬람식 지배와 정부의 이슬람 국가기구(OIC: Organisation of Islamic Countries) 가입에 반발하면서 기독교를 중심으로 하는 종족과 무슬림을 중심으로 하는 종족간의 갈등이 더욱 심화되고 있다. 이는 특히 북부 지역으로 이주한 남동부, 기독교 중심의 이보족과 북부지역 무슬림을 중심으로 하는 하우사-풀라니족 사이에서 빈번히 발생하고 있는데 하우사족과 풀라니 족은 유사한 언어를 사용하여 형제 종족으로 서로 간의 유대가 강한 편이다. 이러한 갈등은 연방정부 운영의 예산 배분에 있어서도 영향을 미치는 것으로 알려지고 있다. 남부의 경우 기독교를 기반으로 한 서구교육을 중심으로 북부는 이슬람교를 기반으로 한 전통교육방식을 고수하는 경향을 나타내는데 교육방식의 차이는 있긴 하지만 이러한 이유로 일반적인 학력 수준이 남부가 보다 높게 나타나는 편이다. 그러나 나이지리아 연방헌법에서는 공무원직을 민족별 할당제로 임명하게 하고 있어, 교육수준이 낮은 북부출신이 수적으로 우세하여 남부에 비해 일찍 고위직에 진출하는 경향이 있었다. 또한 남부 지배계층의 경우, 북부 지배계층에 반해 권력자로서의 위치가 미약한 편이고 북부 지배계층이 국가 전체의 정치, 경제적인 면에서 상대적으로 더 우위의 영향력을 지니고 있는 것으로 평가되고 있다. 이는 앞서 '상대적 결핍이론'에서 잠시 살펴본 바대로 남부 지역의 종족이 북부에 비해 상대적으로 더 박탈되었다는 인식을 강하게 하고 편견과 사회저항을 보다 강하게 할 수 있다. 이처럼 종족과 종교가 복잡하게 얽혀있는 갈등은 북부 지역 출신 대통령의 갑작스런 죽음 하나만으로도 국가 전체가 흔들릴 만큼 심각한 갈등의 동인으로 작용하기도 한다. 2007년 대통령에 취임한 북부 이슬람 출신의 우마루 야라두아(Umaru Yar'Adua)가 2010년 병으로 사망하자, 당시 부통령이었던 굿럭 조나단(Goodluck Jonathan) 대통령직을 승계하였고 남부 기독교 출신의 이 대통령은 이듬해 2011년 4월 대선에서 승리했다. 남과 북의 출신이 8년씩 대통령을 맡기로 한 정치권의 합의를 어기고 북부 출신 야라두아 전 대통령이 사망한 후 남부 출신인 조나단이 대통령직을 가로챈 것으로 보는 시각 때문에 남부 기독교를 기반으로 하는 종족과 북부 이슬람을 기반으로 하는 종족간의 갈등은 더욱 심화되었다 (박경덕 2013:198 201; 외교통상부 2011:65 66).

11) CIA, World fact book 검색 (2014.04) 


\section{2) 갈등의 주요 현황과 특징}

갈등은 북부지역이 남부지역보다 훨씬 낙후함에 따른 불평등, 목축업자인 무슬림과 농부인 기독교인들 간의 토지 분쟁 등이 갈등의 골을 더욱 깊게 하는 주요 원인이 되고 있다. 갈등의 주요 현황 및 특징을 요약하면 다음과 같다(표 3 참조).

$<$ 표 3> 갈등의 주요 현황 및 특징

\begin{tabular}{|c|c|}
\hline 갈등 주요 현황 & 내용 및 특징 \\
\hline $\begin{array}{l}\text { - 오바산조 대통령의 지반자치제 시행 (1999년 ) } \\
\text { - 북부지방의 } 12 \text { 개 주에서 이슬람 율법인 샤리아 } \\
\text { (Sharia)를 기준으로 한 통치를 선언 }\end{array}$ & $\begin{array}{l}\text { - 북부에 살고 있는 기독교인들이 자신들에 대한 박해라고 } \\
\text { 인지하고 격하게 반발, 역으로 남부지역에 있는 기독교인 } \\
\text { 들이 무슬림들을 박해하기 시작 } \\
\text { - 남부지역의 기독교인들이 무슬림을 살해 } \\
\text { - 이로 인한 수천명의 무슬림이 피난행렬에 돌입하고 북부 } \\
\text { 4개 주의 주지사들이 샤리아를 철회하는 데 동의 } \\
\text { - 그럼에도 불구하고 북부지역에서 교회와 무슬림 사원이 } \\
\text { 번갈아 불타고 남/북부 출신 상호간의 유혈충돌이 발생 } \\
\text { - 3개월간 } 1,000 \text { 명 사망 }\end{array}$ \\
\hline $\begin{array}{l}\text { - 국가 빈곤완화 프로그램의 수장으로 북부, } \\
\text { 무슬림 출신이 임명(2001년) }\end{array}$ & $\begin{array}{l}\text { - 서로 다른 종교/종족 출신 배경을 가진 주민들이 혼합거주 } \\
\text { 하는 중부지역(Middle Belt)에서 유혈 충돌 }\end{array}$ \\
\hline $\begin{array}{l}\text { - 남부 기독교 타록족이 남부지역에 거주하는 } \\
\text { 북부 무슬림 플라니족이 소유하고 있는 } \\
\text { 가축들을 대량 도살 }\end{array}$ & - 1,000 여명 사망 \\
\hline - 북부 무슬림 출신 야라두아 대통령 확정 & - 각 해당 출신별 종족간의 분쟁 격화 \\
\hline - 남부 출신 조나단 대통령의 재선 & $\begin{array}{l}\text { - 북부 지역, 단 한주에서도 승리를 거두지 못하고 남부, } \\
\text { 기독교 출신들과 대규모 충돌 발생 } \\
\text { - 3일간의 폭동으로 } 800 \text { 여명 사망, } 65,000 \text { 명이 피난 }\end{array}$ \\
\hline
\end{tabular}

출처: KIDA, World War Watch 홈페이지, '나이지리아 분쟁” 내용을 참고하여 저자 작성

위와 같이 상이한 지역적 배경과 종교를 지닌 종족 간의 갈등과 충돌은 지속적으로 이뤼지고 있으며, 특히 이러한 주민들이 혼합하여 거주하는 중간 지점에서 빈번하게 발생, 인력 손실 뿐 아니라 각종 인프라시설의 파괴 등으로 인해, 지속적인 안정과 발전에 큰 장애로 작용하고 있다. 


\section{3. 나이지리아의 종족갈등과 빈곤}

통계 데이터의 부족으로 인해 종족, 종교를 기반으로 하는 갈등의 정확한 수치는 파악되고 있지 않지만 약 $40 \%$ 가량이 최근에 발생했다는 점은 흥미롭다(Salawu 2010:345). 특히, 최근 들어서는 서로 다른 종교적 - 인종적 배경을 가진 주민들이 혼합 거주하는 중부지역 뿐 아니라 북부 이슬람 과격세력 보코하람12)을 중심으로 북동부 지역에서 테러 등이 보다 심화되고 있는 추세이다.

나이지리아는 1 인당 GDP가 1,222 달러로 $\mathrm{OECD}$ 국가분류의 중저소득국(LMIC)에 해당되지만 인구의 절반이상이 빈곤층이며, 지역별로 빈곤격차가 크고, 빈곤의 개선속도가 느린 편이다. 게다가 종교, 문화, 종족, 생활환경이 복잡하게 얽혀진 결과로 발생되는 갈등은 이러한 빈곤을 더욱 심화시키고 있는데 지역별로 절대빈곤 상황을 비교해보면, 갈등이 빈번하게 일어나는 중부부터 북부지역에서 빈곤이 더욱 심함을 확인할 수 있다.(그림 6 참조)

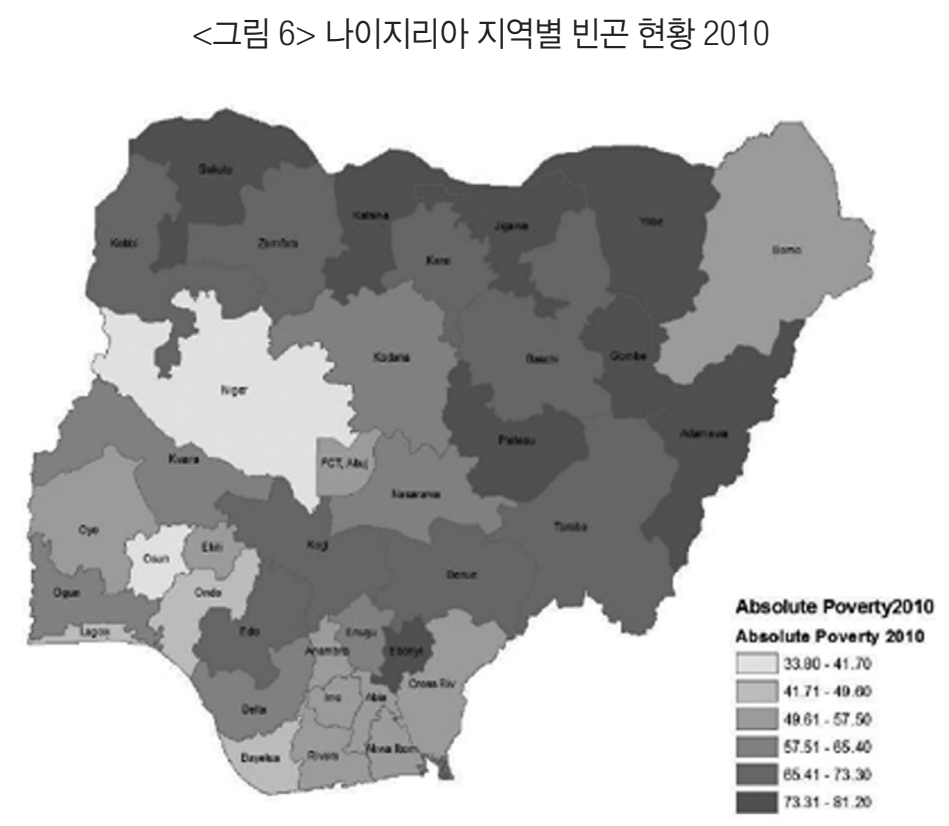

출처: NBS 2010:25

나이지리아의 빈곤현황을 갈등의 발생으로만 확정짓기에는 무리가 있을 수 있지만 갈등이 각종 인프라시설파괴, 치안 불안정 등을 유발하는 측면을 고려할 때상관성을 배제하기는어렵다. 뿐만아니라,

12) 보코하람(Boko Haram)은 '서구식 교육은 신성모독' 이란 뜻으로 나이지리아의 북동부 Borno주 Bauchi 주 등에 기반을 둔 회교 근본주의 단체이다. 이들은 기독교 건물 및 신자들을 공격할 뿐 아니라, 서구식 건축양식이 깃들여진 대형 슈퍼마켓, 학교 등을 무차별 공격하고 있어, 나이지리아의 치안상황을 더욱 불안정하게 만들고 있다. 
주(state) 별 실업 상황을 살펴보더라도 갈등이 잦은 Bauchi(41.4\%)와 중부 지역인 Nasarawa(36.5\%) 에서 나이지리아 평균 실업률(23.9\%) 보다도 월등히 높게 나타난다 ${ }^{13)}$. 이는 나이지리아의 높은 청년층 (youth) 비율을 고려할 때, 이들이 장기간 실업에 쳐하게 되면, 잠재적인 분쟁 요소로 작용할 가능성을 더욱 높게 만들어 ${ }^{14)}$ 치안의 불안정화가 보다 심화되게 만들 수 있으며 이로 인한 종족간의 갈등은 직 간접적으로 그 지역의 여러 환경적 요소와 맞물려 빈곤과 긴밀한 연관관계가 있음을 확인할 수 있다.

\section{V. 정리 및 결론}

제I장

제 II장

타 지역에 비해 유독 빈곤 개선 속도가 느린 사하라이남 아프리카지역에 대해 본고는 종족갈등을 중심으로 빈곤과의 연관성을 살펴보기 위하여 우선, 갈등과 분쟁에 대한 개념 정의로 시작했다. 분쟁이 2개 이상의 행위자 중, 주체가 '국가 또는 정부'로 구성되어야함에도 불구하고 그간 '갈등'과 '분쟁' 은 정확한 의미 구분 없이 혼용되어 왔다. 이에 본고에서는 그 의미를 정확히 다루고 사하라이남 아프리카지역에서 종족 간의 대치로 발생한 사건에 대해'갈등'으로 명명하고 그것이 정부와 대립하는 양상을 나타낼 때에만 '분쟁'으로 보다 명확하게 구분하고자 하였다.

종족 갈등은 최근 들어 아프리카지역의 천연자원의 분배과정에서 드러난 불평등으로 인해 더욱 증폭되고 있는 실정이다. 1960년부터 2013년까지 사하라이남 아프리카지역에서 종족 간의 충돌이 직접적인 갈등의 요인으로 발생된 현황을 살펴본 결과 약 13 건으로 집계되었는데 이는 종료된 것도 있었지만 여전히 진행 중이거나 충돌의 잠재성을 지닌 것도 상당하여 이 지역의 치안을 불안정하게 만들었다. 종족갈등이 발생되고 있는 국가들을 대상으로 인간 삶의 질과 빈곤을 핵심적으로 잘 표현하고 있는 인간개발지수(HDI)를 비교해 본 결과, 이들 대부분 국가의 HDI는 사하라이남 아프리카지역의 평균보다도 낮은 것으로 나타나 종족갈등이 빈곤과 밀접한 연관성을 가지고 있음을 확인할 수 있었다. 특히, 풍부한 자원을 지니고 있음에도 불구하고 빈곤이 획기적으로 개선되지 않으며 이질적인 종교문화를 바탕으로 종족 갈등을 겪고 있는 대표적인 국가인 나이지리아의 사례에서 종족간의 갈등이 빈번하게 일어나는 중부와 북부지역이 타 지역에 비해 빈곤 수치가 보다 높은 것을 확인함으로써 종족갈등과 빈곤의 연관성은 보다 명확해졌다.

그러나 본고는 종족갈등과 빈곤의 연관성은 밝혔지만 인과적 요인을 파악하는 데는 다소 한계점이 있었다. 그럼에도 불구하고 이 지역에 관한 많지 않은 국내의 연구 중, 종족갈등을 중심으로 빈곤을 살피고 특히, 한 국가를 사례를 직접적으로 제시하여 그 관계를 보다 명확히 드러내고자 했다는 측면에서 의미가 있다. 이에 차후 진행되는 연구에서 더 많은 직접적인 사례와 양적 데이터를 기반으로

13) NBS 통계 참조(검색일: 2014.04)

14) 실제 니제르 델타지역의 석유자원 및 주민의 자치권과 관련한 연방정부와의 갈등에서 의용군 및 무장 세력에 학교중퇴자와 청년 실업자등이 다수 포함된 바 있었다. 
종족갈등-빈곤의 관계성에 대해 보다 보완된다면 연구적 의미로 뿐만 아니라, 이 지역의 빈곤 해결의 실질적이고 효과적인 방법을 제시할 수 있다는 측면에서도 매우 의미가 있을 것으로 사료된다.

사하라이남 아프리카지역은 청년층 인구가 대단히 높은 젊은 대륙으로 충분한 자원을 지니고 있다는 측면에서 성장 잠재력이 무궁한 곳으로 전 세계적으로 주목받고 있다. 하지만 이 지역은 식민지시절 임의적인 구분으로 인해 종족, 언어, 문화, 종교의 다양성이 거의 고려되지 못했고 이로 인해 종족갈등이 내재 혹은 발생되고 있었다. 그리고 발전의 잠재성을 충분히 발현되기 어렵게 만드는 여러 환경의 중심에는 결국 이러한 종족 간의 갈등이 내포된 것으로 보였다.

그러나 지금껏 이 지역에 대한 빈곤 개선을 위한 접근에 있어 종족의 다양한 문화, 이해관계를 파악하는 부분은 상대적으로 주요하게 다뤄지지는 않은 편이다. 이에 지금부터라도 종족갈등이 종족의 다양한 측면을 충분히 고려치 않은 자원, 권력 분배 등의 문제와 복잡하게 얽혀 나타나며 이것이 지역정세를 불안정하게 하거나 인적자원이 충분히 개발되지 못하게 함으로써 빈곤개선을 더디게 하는 특성이 있다는 점을 충분히 인지할 필요가 있다. 왜냐하면 종족 간의 갈등은 분쟁으로 표현되기까지 가시성이 약할 수 있지만, 내포하고 있는 문제의 잠재적인 요소를 개선함으로써 이 지역의 효과적인 빈곤개선에 크게 역할 할 것임이 분명하기 때문이다.

이에 우선 각 지역 및 국가의 상이한 종족과 문화에 대한 정확한 정보를 지속적으로 축적해가며 관련한 현장의 경험을 지닌 전문가 양성을 필수적으로 추진해야한다. 더불어 현지에서 관련 경험사례에 대해 공유할 수 있는 네트워킹 확보를 추진함으로써 관련 정보를 관리하고 체계적으로 정리하는 데 보다 효율성을 띨 것이다. 이러한 작업은 중장기적으로 이 지역의 빈곤 완화에 장애가 되는 요소들을 고려할 수 있도록 할 것이다. 그리고 또한 이를 해결책에 직접적으로 반영케 함으로써 이 지역의 빈곤을 보다 빠른 시일 내에 개선하는데 효과적으로 작용하고 나아가 사하라이남 아프리카지역의 발전 가능성을 실질적인 발전으로 이끌 것이다. 


\section{<참고문헌>}

\section{- 국내문헌}

권유경. 2013.『사하라이남 아프리카지역의 젠더불평등과 빈곤』. 영남대학교 박사학위 논문. 김영모 편. 1992.『빈곤이론 빈곤정책』. 한국복지정책 연구소 출판부.

박경덕. 2013. 『말리와 나이지리아의 무장 갈등 형성 요인 연구』. 한국외국어대학교 박사학위

논문.

박영호 · 허윤선 · 심자용. 2008. 「나이지리아의 주요 산업」 『KIEP-KOTRA 유망국가 산업연구』, 08 07. 대외경제정책연구원.

박영호 - 박복영 - 권율 - 허윤선 · 강선주. 2008. 「아프리카 개발협력의 체계적 추진방안」.

『연구보고서』, 08 19. 대외경제정책연구원

외교통상부. 2011.『나이지리아 개황』.

정부부처 합동문서. 2013.『나이지리아 국별협력전략(CPS)』.

최동주. 2006. 「저개발국 내전형 분쟁의 사회경제적 배경: 아프리카 분쟁의 대안적 분석 모델

모색」•『국제지역연구』, 제 9권 제 4호, pp. 363 391.

카를 알브레이트 이멜. 2009.『세계화를 둘러싼 불편한 진실」. 현실문화.

\section{- 국외문헌}

Abdalla bujra. 2000. "African Conflicts: Their Causes and Their Political and Social Environment.” Development Policy Management Forum Occasional Paper, No. 4. Addis Ababa.

APP. 2011. "The Transformative Power of Partnerships". Africa Progress Report. Africa Progress Panel. Geneva. Switzerland.

Azam, Jean-Paul and Christian Morrison. 1999. Conflict and Growth in africa. I. Paris: OECD Development Centre. 재인용: 최동주. 2006. 저개발국 내전형 분쟁의 사회경제적 배경: 아프리카 분쟁의 대안적 분석 모델 모색」. 『국제지역연구』, 제 9 권 제 4 호, pp. 363 391.

Brian-Vincent. 2009. "The Relationship between Poverty, Conflict and Development." Journal of Sustainable Development, Vol. 2, No. 1. 
Deon Filmer, Louise Fox, Kren Brooks, Aparajita Goyal, Taye Mengistae, Patrick Premand, Dena Ringold, Siddharth Sharman and Sergiy Zorya. 2014. Youth Employment in Sub-Saharan Africa. Africa Development Forum. World Bank Washington DC.

DFID. 2001. "The causes of conflict in Africa." Consultation document by the Cabinet Sub-Committee on Conflict Prevention in Africa. 재인용: Jonathan Goodhand. 2001. "Violent conflict, poverty and chronic poverty." CPRC Working Paper, 6. Chronic Poverty Research Centre.

Jonathan Goodhand. 2001. "Violent conflict, poverty and chronic poverty." CPRC Working Paper, 6. Chronic Poverty Research Centre.

NBS. 2010. Nigeria poverty profile. Abuja.

OECD. 2001. The DAC Guidelines poverty reduction. France.

Rasheed Draman. 2003. Poverty and Conflicts in Africa: Explaining a Complex Relationship. Experts Group Meeting on Africa-Canada Parliamentary Strengthening Program. Addis Ababa. May 19 23, 2003.

Salawu B. 2010. "Ethno-Religious Conflicts in Nigeria: Causal Analysis and Proposals for New Management Strategies.” European Journal of Social Sciences, Volume 13.

Tobias, Jutta M., and Karol C. Boudreaux. 2011. "Entrepreneurship and Conflict Reduction in the Post-Genocide Rwandan Coffee Industry”, Journal of Small Business\&Entrepreneurship. 24(2), 재인용: Deon Filmer, Louise Fox, Kren Brooks, Aparajita Goyal, Taye Mengistae, Patrick Premand, Dena Ringold, Siddharth Sharman and Sergiy Zorya. 2014. Youth Employment in Sub-Saharan Africa. Africa Development Forum. World Bank. Washington DC.

UN. 2011. The Millenium Development Goals Report 2011. New York

_.2012. The Millenium Development Goals Report 2012. New York .2013. The Millennium Development Goals Report 2013. New York.

UNDP. 2013. “The Rise of the South: Human Progress in a Diverse World.” Human Development Report 2013. New York. 
UNECA. 2011. "Addressing the youth education and employment nexus in the new global economy.” Africa Youth Report. Addis ababa. Ethiopia

UNECA, AUC, AfDB, UNDP. 2012. "Assessing Progress in Africa toward the MDGs:

Emerging perspectives from Africa on the post-2015 development agenda.” MDG Report 2012.

\section{- 웹사이트}

국립국어원 표준국어대사전

Central bank of Nigeria

CIA, World Factbook

Google, Nigeria tribes map

KIDA, World War Watch

National Bureau of Nigeria 